A

STUDIA Z PRAWA WYZNANIOWEGO

Tom $22-2019$

DOI: https://doi.org/10.31743/spw.4788

\title{
MARCIN OLSZÓWKA*
}

\author{
ANALIZA PROJEKTU USTAWY O ZMIANIE USTAWY \\ O ZAWODACH LEKARZA I LEKARZA DENTYSTY, \\ USTAWY O DIAGNOSTYCE LABORATORYJNEJ \\ ORAZ USTAWY O ZAWODACH PIELĘGNIARKI I POŁOŻNEJ, \\ ZAWARTEGO W DRUKU SENACKIM NR 1034/IX KADENCJA \\ (SPRZECIW SUMIENIA) $^{1}$
}

\section{Streszczenie}

Sprzeciw sumienia to odmowa wykonania obowiązku wynikającego z przepisów prawa ze względu na racjonalnie uzasadniony osąd moralny, który kwalifikuje wykonanie tego obowiązku jako etycznie niegodziwe (obiektywne zło). Prawo do sprzeciwu sumienia - integralny element wolności sumienia - jest konstytucyjnym prawem każdego człowieka. Jak podkreślił Trybunał Konstytucyjny w wyroku z 7 października 2015 r., K 12/14: ,prawo powołania się na klauzulę sumienia i w rezultacie prawo do odmowy wykonania czynności sprzecznej z własnym sumieniem stanowi gwarancję wolności sumienia”. Obowiązkiem ustawodawcy zwykłego jest uregulowanie sposobu korzystania z prawa do sprzeciwu sumienia, czyli ustanowienie tzw. klauzuli sumienia.

Uchwalony przez Komisję Praw Człowieka, Praworządności i Petycji Senatu RP projekt inicjatywy legislacyjnej dotyczącej ustawy o zmianie ustawy o zawodach lekarza i lekarza dentysty, ustawy o diagnostyce laboratoryjnej oraz ustawy o zawodach pielęgniarki i położnej w zamierzeniu miał uregulować klauzule sumienia w zawodach medycznych oraz jednocześnie zrealizować petycję wzywa-

* Dr, Katedra Prawa Administracyjnego, Konstytucyjnego i Prawa Pracy, Wydział Prawa i Administracji, Uczelnia Łazarskiego, ul Świeradowska 43, 02-662 Warszawa, e-mail: marcin.olszowka@lazarski.pl. ORCID 0000-0001-8280-5088.

1 Niniejszy tekst stanowi zaktualizowaną i nieznacznie rozbudowaną wersję analizy opublikowanej 29 stycznia 2019 r. na stronie internetowej Instytutu na rzecz kultury prawnej Ordo Iuris: https://ordoiuris.pl/wolnosc-sumienia/analiza-projektu-ustawy-o-zmianie-ustawy-o-zawodach-lekarza-i-lekarza-dentysty. 
jącą do uchylenia art. 3 ust. 2 ustawy z 17 maja 1989 r. o gwarancjach wolności sumienia i wyznania (generalnie zakazującego powoływania się na sprzeciw sumienia) i kompleksowego wykonania cytowanego wyroku Trybunału.

Choć sama inicjatywa zasługuje na aprobatę, to jednak analiza treści projektu dowodzi, że tylko do pewnego stopnia wykonuje wyrok Trybunału, ignoruje żądanie zawarte w petycji oraz obniża ustawowy standard ochrony prawa do sprzeciwu sumienia.

Na krytykę zasługuje przede wszystkim propozycja zobowiązania podmiotów leczniczych (w praktyce będą to ich kierownicy, np. dyrektor szpitala) do wskazania realnych możliwości uzyskania świadczenia, którego odmówił lekarz lub pielęgniarka (położna), a w przypadku diagnosty laboratoryjnego - do wykonania zlecenia. Narusza bowiem wolność sumienia, która - jak zauważył Trybunał Konstytucyjny - oznacza także ochronę przed postępowaniem, „które pośrednio prowadzi do nieakceptowalnego etycznie skutku, w szczególności przed przymusem współdziałania w osiąganiu celu niegodziwego" (np. przed obowiązkiem informowania, kto i gdzie może wykonać aborcję), jak również kwestionuje tzw. instytucjonalną klauzulę sumienia, do której respektowania wezwało Zgromadzenie Parlamentarne Rady Europy w rezolucji nr 1763 z 7 października 2010 r.

Slowa kluczowe: sprzeciw sumienia; klauzula sumienia; wolność sumienia; zawody medyczne; nadrzędność konstytucji

$* * * * *$

\section{GŁÓWNE TEZY}

I. Prawo do sprzeciwu sumienia, jako integralny element wolności sumienia, jest konstytucyjnym prawem człowieka. Przysługuje każdemu. Obowiązkiem ustawodawcy zwykłego jest uregulowanie sposobu korzystania z prawa do sprzeciwu sumienia, czyli ustanowienie tzw. klauzuli sumienia.

II. Sprzeciw sumienia to odmowa wykonania obowiązku wynikającego z przepisów prawa ze względu na racjonalnie uzasadniony osąd moralny, który kwalifikuje wykonanie tego obowiązku jako etycznie niegodziwe (obiektywne zło). 
III. Wolność sumienia - w tym ten jej element, którym jest sprzeciw sumienia - musi być respektowana niezależnie od tego, czy istnieją przepisy ustawowe ją potwierdzające.

IV. Projekt zakłada uchylenie przepisów ograniczających wolność sumienia lekarzy, które przestały obowiązywać na skutek wyroku Trybunału Konstytucyjnego z 7 października 2015 r. (K 12/14), przez co usuwa źródło potencjalnych konfuzji dotyczących treści aktualnego stanu prawnego w tym zakresie.

V. Projekt zakłada uchylenie niezgodnego z Konstytucją przepisu nakazującego pielęgniarce (położonej), która powołuje się na sprzeciw sumienia, wskazanie realnych możliwości uzyskania tego świadczenia u innej pielęgniarki, położnej lub w podmiocie leczniczym.

VI. Projekt zawiera nowe ograniczenie w powoływaniu się przez lekarza na prawo do sprzeciwu sumienia w postaci obowiązku niezwłocznego poinformowania pacjenta lub jego przedstawiciela ustawowego o fakcie odmowy wykonania świadczenia zdrowotnego ze względu na sprzeciw sumienia, które nie służy ochronie jakichkolwiek konstytucyjnych wolności i praw, jest konfliktogenne, a w konsekwencji stanowi nieproporcjonalne ograniczenie prawa do sprzeciwu sumienia.

VII. Projekt nie zakłada uchylenia ciążącego na pielęgniarkach (położnych) obowiązku poinformowania pacjenta lub jego przedstawiciela ustawowego o fakcie odmowy wykonania świadczenia zdrowotnego ze względu na sprzeciw sumienia, które stanowi nieproporcjonalne ograniczenie korzystania z konstytucyjnego prawa pielęgniarki (położnej) do sprzeciwu sumienia, niesłużące ochronie konstytucyjnych wolności i praw oraz ze swej istoty konfliktogenne.

VIII. Projekt potwierdza prawo do sprzeciwu sumienia diagnosty laboratoryjnego.

IX. Proponowane w projekcie zobowiązanie podmiotów leczniczych do wskazania realnych możliwości uzyskania świadczenia, którego odmówił lekarz lub pielęgniarka (położna), a w przypadku diagnosty laboratoryjnego - do wykonania zlecenia, jest sprzeczne z orzecznictwem Trybunału Konstytucyjnego oraz rezolucją Zgromadzenia Parlamentarnego Rady Europy nr 1763 z dnia 7 października 2010 r. 
X. Projekt nie reguluje klauzuli sumienia dla farmaceutów i właścicieli aptek, błędnie zakładając, że przy wykonywaniu tej profesji medycznej konflikty sumienia nie występują.

XI. Projekt nie zakłada uchylenia przepisów ograniczających wolność (sprzeciw) sumienia, tj. art. 3 ust. 2 ustawy z 17 maja 1989 r. o gwarancjach wolności sumienia i wyznania, oraz wykorzystywanych w celu jej ograniczania, tj. art. 135 i 138 Kodeksu wykroczeń.

\section{PRZEDMIOT ANALIZY}

23 listopada 2018 r. Komisja Praw Człowieka, Praworządności i Petycji Senatu RP (dalej: Komisja) przyjęła uchwałę wnoszącą o podjęcie postępowania w sprawie inicjatywy ustawodawczej dotyczącej projektu ustawy o zmianie ustawy o zawodach lekarza i lekarza dentysty, ustawy o diagnostyce laboratoryjnej oraz ustawy o zawodach pielęgniarki i położ$n^{2}{ }^{2}$ (dalej: projekt). Przygotowany przez Komisję projekt stanowił konsekwencję petycji złożonej w Senacie przez Fundację SPES (P-9-38/17) . $^{\text {. }}$ Celem petycji było wystąpienie $\mathrm{z}$ inicjatywą ustawodawczą uchylającą art. 3 ust. 2 ustawy z dnia 17 maja 1989 r. o gwarancjach wolności sumienia i wyznania ${ }^{4}$, „który narusza konstytucyjnie gwarantowaną wolność sumienia w zakresie, w jakim zmusza obywateli do wykonywania obowiązków sprzecznych $\mathrm{z}$ ich sumieniem, oraz wprowadzenie przepisu potwierdzającego ustalenia Trybunału Konstytucyjnego z wyroku K 12/14 w zakresie, w jakim wskazują, że sprzeciw sumienia należy do istoty wolności sumienia i wyznania”.

Senatorowie postanowili jednak nie zmieniać kontestowanego w petycji niekonstytucyjnego przepisu ustawy i nie formułować na poziomie ustawowym ogólnej klauzuli sumienia (która normatywnie wynika bezpo-

2 Tekst projektu (druk senacki nr 1034/IX kadencja) opublikowany na stronie: https:// www.senat.gov.pl/prace/senat/proces-legislacyjny-w-senacie/inicjatywy-ustawodawcze/inicjatywa,79.html [dostęp: 23.04.2019].

3 Tekst petycji opublikowany na stronie: https://www.senat.gov.pl/gfx/senat/userfiles/_public/k9/dokumenty/petycje_w_pracach_komisji/2018/272pos/p93817/p9-38-17_pet. pdf [dostęp: 23.04.2019].

4 Tekst jedn. Dz. U. z 2017 r., poz. 1153. 
średnio $\mathrm{z}$ art. 53 ust. 1 Konstytucji RP ${ }^{5}$, a przepis ten miał stanowić tylko ustawową gwarancję przestrzegania konstytucyjnego prawa do sprzeciwu sumienia), lecz doprecyzować klauzulę sumienia w ustawach regulujących wykonywanie zawodów medycznych, a mianowicie lekarza (lekarza dentysty), pielęgniarki (położnej) oraz diagnosty laboratoryjnego. Z uzasadnienia projektu wynika również, że Komisja Praw Człowieka, Praworządności i Petycji postanowiła nie proponować nowelizacji ustawy z dnia 6 września 2001 r. - Prawo farmaceutyczne ${ }^{6}$, która wzmocniłaby ustawowe gwarancje korzystania przez farmaceutów z ich konstytucyjnego prawa do sprzeciwu sumienia. Podobnie senatorowie nie opowiedzieli się za uchyleniem art. 135 i 138 Kodeksu wykroczeń7 ${ }^{7}$, które mogą być - i w praktyce są - intepretowane jako w pewnych sytuacjach wykluczające możliwość powoływania się przez przedsiębiorców na konstytucyjne prawo do sprzeciwu sumienia.

\section{ISTOTA KONSTYTUCYJNEJ GWARANCJI WOLNOŚCI SUMIENIA}

Poręczona w art. 53 Konstytucji wolność sumienia - co konsekwentnie powtarza Trybunał Konstytucyjny - nie oznacza jedynie prawa do reprezentowania określonego światopoglądu, ale przede wszystkim prawo do postępowania zgodnie z własnym sumieniem oraz wolność od przymusu postępowania wbrew niemu. Wolność sumienia jest zatem realizowana

5 Konstytucja Rzeczypospolitej Polskiej z dnia 2 kwietnia 1997 r., Dz. U. z 1997 r. $\mathrm{Nr} 78$, poz. 483 z późn. zm.

6 Dz. U. z 2019 r., poz. 499 z późn. zm.

7 Ustawa z dnia 20 maja 1971 r. - Kodeks wykroczeń (Dz. U. z 2019 r., poz. 821 z późn. zm.).

8 Orzeczenie Trybunału Konstytucyjnego z dnia 15 stycznia 1991 r., U 8/90, OTK 1991, nr 1, poz. 8; postanowienie Trybunału Konstytucyjnego z dnia 7 października 1992 r., U 1/92, OTK 1992, Nr 2, poz. 38; wyrok Trybunału Konstytucyjnego z dnia 7 października 2015 r., K 12/14, OTK-A 2015, Nr 9, poz. 143, pkt III.3.3.1 i III.4.2.3. Stanowisko to jest dominujące w doktrynie, np. Szczucki 2009, 168-169; Kubiak 2014, 155-156; Skwarzyński 2013a, 219; Zoll 2014a, 100-101; Nawrot 2014, 108-109, 113-116; Olszówka 2016, 1262-1264; Orzeszyna 2017, 17. Podzielił go również Rzecznik Praw Obywatelskich w „Informacji o działalności Rzecznika Praw Obywatelskich w 2014 roku”, z uwagami o stanie przestrzegania wolności i praw czlowieka i obywatela, s. 123-124 (druk sejmowy nr 3391/ 
zarówno w aspekcie wewnętrznym (kształtowanie własnych ocen moralnych), jak i w aspekcie zewnętrznym (postępowanie w zgodzie z własnym sumieniem $)^{9}$. Prawo do sprzeciwu sumienia to prawo do odmowy wykonania obowiązku wynikającego z przepisów prawa, przysługujące każdemu, kto powołuje się na sprzeciw sumienia, czyli racjonalnie uzasadniony osąd moralny, który kwalifikuje wykonanie tego obowiązku jako etycznie niegodziwe (obiektywne zło) ${ }^{10}$.

W wyroku z 7 października 2015 r. Trybunał Konstytucyjny podkreślił, że w demokratycznym państwie prawnym, ,wyrazem prawa do postępowania zgodnie z własnym sumieniem, a w konsekwencji także wyrazem wolności od przymusu postępowania wbrew własnemu sumieniu, jest klauzula sumienia (...). Wolność sumienia musi bowiem przejawiać się także w możliwości odmowy wykonania obowiązku nałożonego zgodnie z prawem z powołaniem się na przekonania naukowe, religijne lub moralne"11. W konsekwencji prawo powołania się na klauzulę sumienia i w rezultacie prawo do odmowy wykonania czynności sprzecznej z własnym sumieniem stanowi gwarancję wolności sumienia ${ }^{12}$, a nie przywilej przyznany jakiejś grupie. Trybunał Konstytucyjny bardzo wyraźnie podkreślił, że „,wolność sumienia - w tym ten jej element, którym jest sprzeciw sumienia - musi

VII kadencja; opublikowany na stronie: http://orka.sejm.gov.pl/Druki7ka.nsf/0/59CB75C10 8B18623C1257E4400354A4A/\%24File/3391.pdf [dostęp 23.04.2019].

9 Jak trafnie zauważono w piśmiennictwie: ,[o] ile sfera wolności wewnętrznej nie podlega jakiejkolwiek limitacji, o tyle wyjście jednostki z wewnętrznej twierdzy, ekspresja własnych przekonań, uwzględniać musi realia społeczeństwa demokratycznego i jego systemu wartości. W sferze zewnętrznej wolność myśli, sumienia i wyznania może więc, a w niektórych przepadkach wręcz musi - jeśli nie ma dojść do jej hipertrofii i paraliżu państwa - podlegać ograniczeniom.” (Nawrot 2014, 109).

10 Olszówka 2019a, 58. Trybunał Konstytucyjny wyeksplikował klauzulę sumienia jako „możliwość niepodejmowania działania zgodnego z prawem i powinnego, a jednocześnie sprzecznego ze światopoglądem (przekonaniami ideologicznymi czy religijnymi) danej osoby" (wyrok Trybunału Konstytucyjnego z dnia 7 października 2015 r., K 12/14, OTK 2015, Nr 9A, poz. 143, pkt III.4.2.3).

11 Wyrok Trybunału Konstytucyjnego z 7 października 2015 r., pkt III.4.4.1. W literaturze przedmiotu wskazuje się, że np. wśród lekarzy „odmowa świadczeń z przesłanek stricte religijnych wydaje się zjawiskiem marginalnym” (Pawlikowski 2014, 167).

12 Johann, Lewaszkiewicz-Petrykowska 1999, 21. 
być więc respektowana niezależnie od tego, czy istnieją przepisy ustawowe ją potwierdzające" $"$.

Istnienie konstytucyjnych gwarancji prawa do sprzeciwu sumienia może okazać się jednak niewystarczające, aby zapewnić jego efektywną realizację. Dlatego konstytucyjnym obowiązkiem ustawodawcy jest uregulowanie sposobu (a nie zakresu!) korzystania z prawa do sprzeciwu sumienia. Temu właśnie służy klauzula sumienia, czyli przepis (przepisy) ustawy, który określa sposób korzystania z prawa do sprzeciwu sumienia, w tym warunki proceduralne powoływania się na sprzeciw sumienia. Klauzula sumienia pełni również funkcję informacyjną, gdyż przypomina adresatom prawa, że mogą powoływać się na sprzeciw sumienia. W tym zakresie klauzula sumienia buduje świadomość prawną obywateli i wzmacnia gwarancje poszanowania konstytucyjnie poręczonych praw człowieka ${ }^{14}$.

\section{UWAGI SZCZEGÓŁOWE ODNOSZĄCE SIĘ DO TREŚCI PROJEKTU}

\subsection{KLAUZULA SUMIENIA LEKARZA I LEKARZA DENTYSTY}

Art. 1 projektu zakłada nowelizację art. 30 i 39 ustawy z dnia 5 grudnia 1996 r. o zawodach lekarza i lekarza dentysty ${ }^{15} \mathrm{w}$ celu dostosowania brzmienia ustawy do wyroku TK z 7 października 2015 r., K 12/14. Trybunał stwierdził wówczas niekonstytucyjność dwóch norm prawnych wynikających $\mathrm{z}$ wspomnianych przepisów, a mianowicie obowiązku udzielania przez lekarza świadczeń zdrowotnych sprzecznych z jego sumieniem w ,innych przypadkach niecierpiących zwłoki” oraz - w przypadku odmowy udzielenia świadczenia - obowiązku wskazania realnych „możliwości uzyskania tego świadczenia u innego lekarza lub w podmio-

13 Wyrok Trybunału Konstytucyjnego z 7 października 2015 r., pkt III.4.4.3.

14 Olszówka 2019b, 218. Trafnie zwrócono uwagę w doktrynie, że „wąskie rozumienie wolności sumienia i służącej jej urzeczywistnieniu w wymiarze zewnętrznym klauzuli sumienia, jest sprzeczne z aksjologią praw człowieka i demokratycznego państwa prawnego, a nawet - z samą istotą społeczeństwa demokratycznego i państwa prawnego", zaś prawo do sprzeciwu sumienia ,nigdy nie może być traktowane jako pochodzące od prawodawcy, lecz jako element zastanej rzeczywistości, w której prawodawca funkcjonuje” (Nawrot 2016, 141).

15 Tekst jedn. Dz. U. z 2019 r., poz. 537 z późn. zm. 
cie leczniczym". Zgodnie z art. 190 Konstytucji RP uznane za niezgodne z Konstytucją normy prawne utraciły moc prawną wraz z publikacją wyroku. Nie zmienił się jednak tekst ustawy, co szczególnie u nie-prawników, może budzić wątpliwości co do obowiązującego stanu prawnego ${ }^{16}$. Opublikowany w Dzienniku Ustaw tekst jednolity ustawy zawiera wprawdzie przyp. nr 6 o treści: ,„[z]danie pierwsze uznane za niezgodne z Konstytucją z dniem 16 października 2015 r. w zakresie, w jakim nakłada na lekarza obowiązek wykonania niezgodnego z jego sumieniem świadczenia zdrowotnego w «innych przypadkach niecierpiących zwłoki» oraz w jakim nakłada na lekarza powstrzymującego się od wykonania świadczenia zdrowotnego niezgodnego $\mathrm{z}$ jego sumieniem obowiązek wskazania realnych możliwości uzyskania takiego świadczenia u innego lekarza lub w innym podmiocie leczniczym, na podstawie wyroku Trybunału Konstytucyjnego z dnia 7 października 2015 r. sygn. akt K 12/14 (Dz. U. poz. 1633)" - ale raczej nie ułatwia to identyfikacji i zrozumienia obowiązującej treści normatywnej, w szczególności tego, jakie obowiązki ustawodawca nakłada na lekarza powołującego się na sprzeciw sumienia.

Projekt zakłada odpowiednie przeredagowanie brzmienia art. 39 (i art. 30) ${ }^{17}$ ustawy, tak, aby nie sugerował już, że nadal obowiązują niekon-

16 Przykładem dezinformacji obecnej w środkach masowego przekazu może być artykuł W. Ferfeckiego, Klauzula sumienia nie tylko dla lekarzy, https://www.rp.pl/ Polityka/311229912-Klauzula-sumienia-nie-tylko-dla-lekarzy.html, w którym podana jest sprzeczna z aktualnym stanem prawnym informacja, że lekarz ,powołujący się na sprzeciw sumienia ma też obowiązek wskazać możliwość uzyskania świadczenia u innego medyka" [dostęp: 23.04.2019].

17 Należy zauważyć, że nowelizacja art. 30 nie wydaje się niezbędna, ponieważ wystarczająca byłaby zmiana brzmienia tylko przepisu art. 39 poprzez rezygnację z odesłania do art. 30 (techniki legislacyjnie dopuszczalnej, ale utrudniającej rekonstrukcję treści normatywnej przepisu) oraz enumeratywne wyliczenie przypadków, gdy lekarz nie może powołać się na sprzeciw sumienia (art. 39 mógłby zatem brzmieć np. tak: „Lekarz może powstrzymać się od wykonania świadczeń zdrowotnych niezgodnych z jego sumieniem, chyba że mogłoby to spowodować niebezpieczeństwo utraty życia, ciężkiego uszkodzenia ciała lub ciężkiego rozstroju zdrowia, z tym że ma obowiązek odnotować ten fakt w dokumentacji medycznej. Lekarz wykonujący swój zawód na podstawie stosunku pracy lub w ramach służby ma ponadto obowiązek uprzedniego powiadomienia na piśmie przełożonego. Brak powiadomienia przełożonego nie wpływa na prawo lekarza do powołania się na sprzeciw sumienia, o którym mowa w zdaniu pierwszym.”). 
stytucyjne normy prawne. Z perspektywy realizacji zasady nadrzędności konstytucji (art. 8 Konstytucji) i poszanowania wolności sumienia (art. 53 Konstytucji) przygotowany projekt w tej części zasługuje na aprobatę.

Niemniej projektodawca proponuje jednocześnie nałożenie na lekarzy powołujących się na sprzeciw sumienia nowych, dodatkowych ograniczeń, choć w uzasadnieniu deklaruje, że ,starano się w tylko minimalnym stopniu ingerować w treść ustaw"18. Ponieważ konstytucyjne prawo do sprzeciwu sumienia jest zasadą, a ustanawianie ograniczeń w korzystaniu zeń dopuszczalne jest dopiero po spełnieniu określonych warunków ${ }^{19}$, należy ocenić, czy proponowane ograniczenia nie naruszają wymogów określonych w art. 31 ust. 3 Konstytucji, w szczególności kryterium materialnego (identyfikacja wartości usprawiedliwiającej ograniczenie) oraz testu proporcjonalności (przydatności, konieczności i proporcjonalności sensu stricto $)^{20}$.

W pierwszej kolejności Komisja proponuje, aby lekarz powołujący się na klauzulę sumienia każdorazowo miał obowiązek „niezwłocznego uprzedzenia pacjenta lub jego przedstawiciela ustawowego bądź opiekuna faktycznego o takiej odmowie" (np. udziału w aborcji). Aktualny stan prawny słusznie nie przewiduje takiego obowiązku, gdyż jest on wysoce wątpliwy tak pod względem prakseologicznym, jak i jego zgodności z Konstytucją. Jest tak przynajmniej z trzech powodów. Po pierwsze, samo poinformowanie pacjenta o tym, że lekarz odmawia podjęcia jakiejś czynności w żaden sposób nie przybliża pacjenta do uzyskania oczekiwanego świadczenia ani nie stanowi informacji o jego stanie zdrowia czy innych kwestiach wchodzących w zakres ustawowego prawa pacjenta do informacji ${ }^{21}$. Po drugie, stwarza to sytuację potencjalnie konfliktową pomiędzy pacjentem a lekarzem, szczególnie jeśli wcześniej nie mieli ze sobą stycz-

18 Druk senacki nr 1034/IX kadencja, uzasadnienie, s. 3.

19 Wyrok Trybunału Konstytucyjnego z 7 października 2015 r., pkt III.4.4; Zoll 2014b, 79-80; Szczucki 2009, 168-169; Nawrot 2016, 144-145; Olszówka 2016, 1263; Orzeszyna $2017,17,26$.

20 Szerzej na temat zasady proporcjonalności zob. Szydło 2016, 785-807.

21 Zob. art. 9-12 ustawy z dnia 6 listopada 2008 r. o prawach pacjenta i Rzeczniku Praw Pacjenta (tekst jedn. Dz. U. z 2019 r., poz. 1127 z późn. zm.). 
ności ${ }^{22}$ (oczywiście w hipotetycznej sytuacji, gdy pacjent bezpośrednio zażąda od lekarza zachowania budzącego sprzeciw sumienia, ten ostatni postawiony jest w sytuacji, gdy poinformowanie pacjenta jest konieczne - niemniej wynika to z istoty rzeczy i nie wymaga szczególnej regulacji ustawowej). Po trzecie, projektowane ograniczenie może wywołać „efekt mrożący" wśród lekarzy, którzy chcąc uniknąć kłótni z pacjentem (raczej niepolepszających jego stanu zdrowia) i ewentualnych sporów etycznych na sali szpitalnej, w praktyce mogą rezygnować $\mathrm{z}$ działania w zgodzie z własnym sumieniem, co jest niedopuszczalne w świetle konstytucyjnej wolności sumienia. W konsekwencji skonstatować trzeba, że projektowane ograniczenie w korzystaniu ze sprzeciwu sumienia lekarza jest nieproporcjonalne, ponieważ nie znajduje uzasadnienia w żadnej z wartości wymienionych w art. 31 ust. 3 Konstytucji i nie jest konieczne, a wręcz niepożądane z punktu widzenia realizacji konstytucyjnych wolności i praw, tak lekarza, jak i pacjenta.

Kolejna istotna nowość proponowana w projekcie - wbrew wspomnianej deklaracji zawartej w uzasadnieniu - to nałożenie na podmiot leczniczy, w przypadku powstrzymania się przez lekarza od wykonania świadczenia zdrowotnego, obowiązku wskazania lekarza lub podmiotu wykonującego działalność leczniczą, który zapewni realną możliwość wykonania tego świadczenia (tzw. obowiązku informacyjnego) ${ }^{23}$. Propozycja ta budzi bar-

22 Taka sytuacja szczególnie często wystąpić może w związku z aborcją. Zgodnie z art. 4a ust. 5 ustawy z dnia 7 stycznia 1993 r. o planowaniu rodziny, ochronie płodu ludzkiego i warunkach dopuszczalności przerywania ciąży (Dz. U. Nr 17, poz. 78 z późn. zm.) wystąpienie okoliczności, o których mowa w art. 4a ust. 1 pkt 1 i 2 -wyłączających karalność aborcji ze względu na zagrożenie życia lub zdrowia matki albo duże prawdopodobieństwo ciężkiego i nieodwracalnego upośledzenia dziecka, albo nieuleczalnej choroby zagrażającej jego życiu - stwierdza inny lekarz niż dokonujący przerwania ciąży (z zastrzeżeniem sytuacji bezpośrednio zagrożenia życia kobiety). Oznacza to, że w przypadku wejścia w życie proponowanych przepisów, lekarz odmawiający prenatalnego zabicia dziecka będzie musiał oznajmić ten fakt matce dziecka, zapewne przy okazji przedstawiając się, ponieważ wcześniej nie miał takiej sposobności, jako że nie była ona jego pacjentką. Trudno odgadnąć, jaki cel przyświecał pomysłodawcy tego przepisu, natomiast z dużym prawdopodobieństwem częstym skutkiem jego stosowania będą sytuacje konfliktowe powstałe między pacjentem a lekarzem powołującym się na sprzeciw sumienia, których prawodawca powinien unikać, a nie katalizować.

23 W literaturze przedmiotu wyrażono pogląd, że nałożenie na lekarzy obowiązku informacyjnego (bezpośredni współudział w osiągnięciu skutku niegodziwego, objętego 
dzo poważne wątpliwości w świetle konstytucyjnej gwarancji wolności sumienia, której konsekwencje opisane zostały w motywach uzasadnienia wyroku TK z 2015 r. (K 12/14). Trybunał stwierdzając niezgodność z ustawą zasadniczą normy prawnej nakazującej lekarzowi wskazanie osoby lub miejsca udzielenia świadczenia zdrowotnego budzącego jego sprzeciw sumienia, wskazał, że obowiązek ten nie powinien ciążyć również na podmiotach leczniczych, lecz na organach władzy publicznej, zwłaszcza na Narodowym Funduszu Zdrowia, który „nie powinien, przez narzucenie obowiązku wykonywania określonego świadczenia, jako warunku sine qua non zawarcia umowy, wymuszać wykonywania przez podmioty lecznicze świadczeń «wrażliwych moralnie», a co za tym idzie - nie powinien wymuszać kształtowania personelu medycznego tych podmiotów według kryterium sumienia. Celowe wydaje się odrębne kontraktowanie owych świadczeń i utrzymywanie przez NFZ aktualnej wiedzy o wykonujących je podmiotach, ponieważ to na organach władzy publicznej, a nie na lekarzach lub nawet na podmiotach leczniczych, spoczywa obowiązek zagwarantowania, że świadczenia finansowane ze środków publicznych będą dostępne na równych zasadach."

Wykonaniem zawartej w uzasadnieniu wyroku Trybunału Konstytucyjnego wyraźnej dyrektywy o niedopuszczalności wymuszania wykonywania przez podmioty lecznicze świadczeń „wrażliwych moralnie” byłoby ustawowe zagwarantowanie, że mogą one powstrzymywać się od wykonywania określonych świadczeń i usług (po publicznym tego ogłoszeniu), w szczególności aborcji ${ }^{24}$. Wprawdzie w doktrynie jest obecny

sprzeciwem sumienia) mogło stanowić naruszenie istoty wolności sumienia, co jest bezwzględnie zakazane na gruncie art. 31 ust. 3 zd. drugie w zw. z art. 53 ust. 1 Konstytucji (Nawrot 2016, 147; Bosek 2014b, 102), do którego to stanowiska należy się przychylić.

24 Cel ten można by osiągnąć, przykładowo, poprzez dodanie w art. 15 ustawy z dnia 15 kwietnia 2011 r. o działalności leczniczej (tekst jedn. Dz. U. z 2018 r., poz. 2190) ust. 2 o treści: ,[p]odmiot leczniczy może odmówić udzielenia świadczenia, o którym mowa w art. 4b ustawy z dnia 7 stycznia 1993 r. o planowaniu rodziny, ochronie płodu ludzkiego i warunkach dopuszczalności przerywania ciąży (Dz. U. Nr 17, poz. 78, z 1995 r. Nr 66, poz. 334, z 1996 r. Nr 139, poz. 646, z 1997 r. Nr 141, poz. 943, z 1999 r. Nr 5, poz. 32 oraz z 2001 r. Nr 154, poz. 1792), chyba że zwłoka w udzieleniu tego świadczenia mogłaby spowodować bezpośrednie zagrożenie życia matki”. Oczywiście z punktu widzenia poszanowania konstytucyjnej wolności sumienia wprowadzenie kompleksowej, wyraźnej instytu- 
pogląd ${ }^{25}$, że już aktualnie na podstawie normy stanowiącej, iż podmiot leczniczy podaje do wiadomości publicznej informacje o zakresie i rodzajach udzielanych świadczeń zdrowotnych, dopuszczalne jest, aby dany podmiot leczniczy nie wykonywał świadczeń określonego rodzaju, tj. ogłosił, że pewnych procedur, np. aborcji, nie wykonuje. Lecz jest to tylko pogląd - oczywiście bardzo słuszny i ostatnio wsparty motywami uzasadnienia cytowanego tu wyroku TK z 2015 r. - który nigdy nie zastąpi jednoznacznego przepisu.

Nałożenie na podmioty lecznicze obowiązku informacyjnego jest także wątpliwe z punktu widzenia adekwatności proponowanego środka. Celem ma być zapewnienie realizacji prawa do ochrony zdrowia i uzyskania przez pacjenta informacji o miejscu (osobie), która wykona żądane świadczenie. Stwierdzając niekonstytucyjność analogicznego obowiązku informacyjnego ciążącego do 2015 r. na lekarzach, Trybunał Konstytucyjny wyraźnie podkreślił, że jego spełnienie ,zakłada stan permanentnego wkraczania przez lekarza w sferę wolności sumienia innych lekarzy, naruszania tajemnicy lekarskiej i reguł rządzących ochroną danych osobowych"26. Uwagi te w pełni należy odnieść do podmiotów leczniczych, które z tych samych powodów również nie powinny posiadać informacji objętych projektowanym obowiązkiem. W systemie prawnym nie istnieje też żaden specjalny mechanizm, który zezwalałby jednemu podmiotowi leczniczemu na gromadzenie danych o zakładach leczniczych, w których pracuje lekarz niezgłaszający sprzeciwu sumienia wobec konkretnego świadczenia ${ }^{27}$.

cjonalnej klauzuli sumienia byłoby rozwiązaniem zdecydowanie bardziej pożądanym, nawet jeśli miałoby dotyczyć jedynie podmiotów leczniczych (zob. przyp. 30 i 31).

25 Bosek 2011, 25.

26 Wyrok Trybunału Konstytucyjnego z 7 października 2015 r., pkt III.6.2.5.

27 Na ten problem, dotyczący w równym stopniu podmiotów leczniczych, które nie zawarły kontraktu z Narodowym Funduszem Zdrowia i świadczą usługi komercyjnie, zwróciła uwagę - między innymi - także Prokuratoria Generalna Rzeczypospolitej Polskiej (pismo z dnia 28 grudnia 2018 r. do Przewodniczącego Komisji Ustawodawczej Senatu RP, s. 4; dostępne na stronie: https:/www.senat.gov.pl/prace/senat/proces-legislacyjny-w-senacie/ inicjatywy-ustawodawcze/inicjatywa,79.html), która krytycznie oceniła zobowiązanie podmiotów leczniczych do wskazania realnych możliwości wykonania świadczenia, którego odmówił lekarz lub pielęgniarka (położna). 
Ponadto nałożenie obowiązku informacyjnego koliduje z apelem Zgromadzenia Parlamentarnego Rady Europy wyrażonym w rezolucji nr 1763 $\mathrm{z}$ dnia 7 października $2010 \mathrm{r}$. w sprawie prawa do sprzeciwu sumienia w ramach legalnej opieki medycznej (ang. The right to conscientious objection in lawful medical care $)^{28}$. W pkt 1 rezolucji wskazano, że żadna osoba, szpital lub instytucja nie mogą zostać prawnie przymuszone, pociągnięte do odpowiedzialności prawnej ani dyskryminowane z powodu odmowy przeprowadzenia, udzielenia asystowania lub podporządkowania się wykonaniu aborcji, spowodowania poronienia, przeprowadzenia eutanazji lub innego czynu, który mógłby spowodować śmierć zarodka ludzkiego lub embrionu z jakiegokolwiek powodu. Rezolucja nie ma oczywiście mocy wiążącej, niemniej stanowi wyraz troski organizacji międzynarodowej, powołanej m.in. do ochrony praw człowieka, o kompleksowe poszanowanie wolności sumienia wszystkich osób, w tym także kierowników zakładów leczniczych, szczególnie tych, które w swej działalności kierują się pewnymi normami moralnymi (tzw. etosem organizacji). Podkreślić trzeba, że koncepcja tzw. instytucjonalnej klauzuli sumienia nie jest niczym niespotykanym ${ }^{29}$. Prawo spółki do sprzeciwu sumienia (motywowanego religijnie) potwierdził Sąd Najwyższy USA w wyroku z dnia 30 czerwca 2014 r. w sprawie Burwell v. Hobby Lobby Stores ${ }^{30}$. W ponad 40 stanach amerykańskich prawo - w różnym zakresie - gwarantuje osobom prawnym (instytucjom) świadczącym usługi medyczne prawo do odmowy wykonywania różnych procedur i zabiegów budzących wątpliwości etyczne ${ }^{31}$.

Przywołując raz jeszcze wyrok Trybunału Konstytucyjnego z 2015 r., należy zacytować zawartą w uzasadnieniu konstatację, że ,[k]onstytucyj-

28 Tekst rezolucji w języku angielskim opublikowany na stronie: http://assembly.coe.

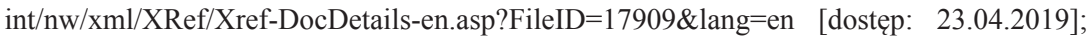
polskie tłumaczenie: Pawlikowski 2011, 336-337.

${ }^{29} \mathrm{~W}$ polskiej literaturze przedmiotu o zagadnieniu tym piszą: Bosek 2014a, 19-20; Roszkiewicz 2018, 172-177, 187-188; Olszówka 2016, 1263-1264.

30 Zob. szerzej Roszkiewicz 2018, 183-187; zob. także K. Dyda, Analiza tendencji $w$ orzecznictwie Sądu Najwyższego USA w zakresie ochrony wolności sumienia i religii, pkt 5, https://ordoiuris.pl/wolnosc-sumienia/analiza-tendencji-w-orzecznictwie-sadu-najwyzszego-usa-w-zakresie-ochrony-wolnosci [dostęp: 23.04.2019].

31 Guttmacher Institute, Refusing to Provide Health Services, https://www.guttmacher. org/state-policy/explore/refusing-provide-health-services [dostęp: 7.01.2019]. 
na gwarancja wolności sumienia chroni bowiem jednostkę nie tylko przed przymusem podjęcia bezpośredniego zamachu na chronione dobro, lecz także przed takim postępowaniem niezgodnym z sumieniem jednostki, które pośrednio prowadzi do nieakceptowalnego etycznie skutku, w szczególności przed przymusem współdziałania w osiąganiu celu niegodziwego"32. Sprzeciw sumienia ex definitione obejmuje bowiem różne formy zjawiskowe czynu (zachowania), nie tylko samo wykonanie, pomoc, asystowanie, przygotowywanie, akceptowanie czy pośredniczenie, lecz również informowanie o możliwości (osobie, miejscu) jego dokonania.

Kolejna zmiana przewidziana przez projekt nakłada na lekarzy prowadzących indywidualną praktykę lekarską w zakładzie leczniczym na podstawie umowy z podmiotem leczniczym prowadzącym ten zakład obowiązek uprzedniego powiadomienia na piśmie przełożonego o powstrzymaniu się od wykonania świadczeń zdrowotnych ze względu na sprzeciw sumienia (tzw. obowiązek notyfikacyjny). Do tej pory analogiczny obowiązek spoczywał na lekarzach wykonujących swój zawód na podstawie stosunku pracy lub w ramach służby. W wielokrotnie przywoływanym tu wyroku Trybunał uznał ten wymóg za zgodny z Konstytucją ${ }^{33}$. Nie wydaje się zatem, aby rozszerzenie tego rodzaju ograniczenia w korzystaniu ze sprzeciwu sumienia na lekarzy wykonujących swój zawód w innej formie prawnej budziło wątpliwości natury konstytucyjnej. Ważne jednak, aby brak takiego powiadomienia nigdy nie był interpretowany jako rezygnacja przez lekarza z przysługującego mu prawa do sprzeciwu sumienia bądź warunek sine qua non powoływania się na nie ${ }^{34}$.

32 Wyrok Trybunału Konstytucyjnego z 7 października 2015 r., pkt III.6.2.1.

33 W tym zakresie zdanie odrębne zgłosiła sędzia TK T. Liszcz, a w doktrynie pogląd odmienny od Trybunału wyraził Bosek 2014b, 103.

34 W odróżnieniu od propozycji Komisji Praw Człowieka, Praworządności i Petycji Senatu RP przygotowany przez Ministra Zdrowia, datowany na 31 maja 2019 r., projekt ustawy o zmianie ustawy o zawodach lekarza i lekarza dentysty oraz niektórych innych ustaw (opublikowany na stronie: https://legislacja.rcl.gov.pl/projekt/12321898/katalog/12597842\#12597842 [dostęp: 20.07.2019]), który również wykonuje wyrok TK z 7 października 2015 r. (art. 1 pkt 61 i 62), nie zawierał niezgodnych z Konstytucją propozycji, wypunktowanych w niniejszym tekście. Warto dodać, iż projekt nie tylko zakłada pełne wykonanie wspomnianego orzeczenia, lecz także wprowadzenie dwóch dodatkowych zmian, tj. w przypadku niecierpiącym zwłoki likwidację obowiązku udzielania pomocy lekarskiej (TK orzekał o obowiązku udzielania świadczeń zdrowotnych, co jest pojęciem szerszym - zob. wyrok TK z 7 października 2015 r., 


\subsection{DIAGNOŚCI LABORATORYJNI}

Analizowany projekt zakłada nowelizację ustawy z dnia 27 lipca $2001 \mathrm{r}$. o diagnostyce laboratoryjnej ${ }^{35}$ poprzez sformułowanie klauzuli sumienia diagnosty laboratoryjnego. W świetle projektowanej regulacji jedynym ograniczeniem w powoływaniu się na sprzeciw sumienia przez diagnostę laboratoryjnego ma być obowiązek niezwłocznego powiadomienia na piśmie swojego bezpośredniego przełożonego (projektowany art. 28a ust. 1$)^{36}$. Obowiązek ten nie budzi wątpliwości konstytucyjnych, o ile nie będzie rozumiany jako wykluczający złożenie , generalnej klauzuli sumienia”, tj. wobec czynności określonego rodzaju, czyli jako zobowiązujący do składania odrębnej odmowy przy każdym kolejnym zleceniu, nawet jeżeli dotyczy czynności tego samego rodzaju. Projektowaną klauzulę sumienia warto by uzupełnić zastrzeżeniem, że powołanie się na sprzeciw sumienia jest wyłączone w przypadkach, gdyby mogło to spowodować niebezpieczeństwo utraty życia, ciężkiego uszkodzenia ciała lub ciężkiego rozstroju zdrowia (analogicznie jak w przypadku zawodu lekarza), nawet jeśli statystycznie takie przypadki występują bardzo rzadko ${ }^{37}$.

K 12/14, pkt III.4.3) oraz likwidację obowiązku uzasadnienia sprzeciwu sumienia (pozostawia jedynie obowiązek odnotowania tego faktu w dokumentacji medycznej), który jest przedmiotem krytyki w doktrynie (Bosek 2014b, 98-99). Niestety w późniejszej wersji projektu nowelizacji pojawił się niezgodny z Konstytucją przepis nakładający obowiązek informacyjny na podmioty lecznicze i w takim kształcie projekt został przyjęty przez Radę Ministrów 7 stycznia 2020 r. i wniesiony do laski marszałkowskiej 16 stycznia (druk sejmowy nr 172/IX kadencja). W przyjętym 25 lutego 2020 r. sprawozdaniu podkomisji nadzwyczajnej do rozpatrzenia rządowego projektu ustawy o zmianie ustawy o zawodach lekarza i lekarza dentysty oraz niektórych innych ustaw wraz z autopoprawką (druki nr 172 i 172-A) przepis ten nie został uchylony, pomimo podnoszonych podczas posiedzenia podkomisji głosów krytycznych, w tym ze strony Instytutu Ordo Iuris oraz Naczelnej Rady Lekarskiej (szczegóły na stronie internetowej: http:// sejm.gov.pl/Sejm9.nsf/PrzebiegProc.xsp?nr=172).

35 Tekst jedn. Dz. U. z 2019 r., poz. 849 z późn. zm.

36 Aczkolwiek ratio legis umieszczenia projektowanego przepisu po art. 28 nie budzi poważniejszych zastrzeżeń, to jednak wydaje się, że lepszym rozwiązaniem byłoby umiejscowienie tego przepisu po art. 21, czyli jako art. 21a.

37 Diagności laboratoryjni najczęściej powołują się na sprzeciw sumienia, odmawiając przeprowadzenia badań komórek, które są wykorzystywane w procedurze zapłodnienia pozaustrojowego, albo badań, których wyniki mogą być podstawą uznania aborcji konkretnego 
Ponadto projektodawca proponuje, aby na podmiocie leczniczym, w którym diagnosta laboratoryjny odmówił wykonania zlecenia lekarskiego ze względu na sprzeciw sumienia, ciążył ustawowy obowiązek zapewnienia wykonania tego zlecenia. W odróżnieniu od zakładanej zmiany w ustawie o zawodzie lekarza nie chodzi tu o udzielenie informacji o podmiocie, który wykona to zlecenie, lecz o to, aby to podmiot leczniczy, w którym diagnosta laboratoryjny odmówił wykonania zlecenia ze względu na sprzeciw sumienia, zapewnił wykonanie tego zlecenia. W praktyce musi to oznaczać, że każdy podmiot leczniczy wykonujący czynności diagnostyki laboratoryjnej będzie zmuszony zatrudniać lub współpracować z diagnostą laboratoryjnym, który nie zgłasza sprzeciwu sumienia, co z kolei stanowić będzie formę dyskryminacji diagnostów go zgłaszających. Tymczasem Trybunał Konstytucyjny w wyroku z 7 października 2015 r. zauważył, że konsekwencją powoływania się na sprzeciw sumienia przez pracowników podmiotu leczniczego jest zdolność ,tegoż podmiotu do wykonywania określonych świadczeń" 38 . Innymi słowy, jeśli osoby zatrudnione w danym podmiocie leczniczym (współpracujące z nim) nie wykonują określonych czynności z przyczyn etycznych, nie może być on obowiązany do zapewnienia wykonania tychże czynności. Taki jest również cel informowania przełożonego o odmowie wykonania zlecenia lekarskiego ze względu na sprzeciw sumienia. Ponadto należy mieć na uwadze konieczność respektowania tzw. instytucjonalnej klauzuli sumienia - do czego wezwało Zgromadzenie Parlamentarne Rady Europy - gdyż również podmiot leczniczy zajmujący się diagnostyką laboratoryjną ma prawo w swej działalności kierować się określoną misją i zasadami moralnymi.

Trzeba jeszcze koniecznie zauważyć, że - niezależnie od gwarancji konstytucyjnych - zgodnie z art. 21 ustawy o diagnostyce laboratoryjnej przedstawiciele tej profesji medycznej mają obowiązek postępować m.in. zgodnie z zasadami etyki zawodowej. Te ostatnie zapisane są w Kodeksie Etyki Diagnosty Laboratoryjnego ${ }^{39}$, który w $§ 22$ wprost potwierdza

dziecka poczętego za niekaralną w świetle polskiego prawa, lub wykonania morfologii krwi przeznaczonej do transfuzji (Głusiec, Puacz 2014, 232-234).

38 Wyrok Trybunału Konstytucyjnego z 7 października 2015 r., pkt III.7.2.1.

39 Załącznik do uchwały nr 31/2014 Czwartego Krajowego Zjazdu Diagnostów Laboratoryjnych z dnia 6 grudnia 2014 r. w sprawie Kodeksu Etyki Diagnosty Laboratoryjnego; tekst opublikowany na stronie: http://kidl.org.pl/uploads/Kodeks_etyki_2015.pdf [dostęp: 23.04.2019]. 
prawo diagnosty laboratoryjnego do sprzeciwu sumienia i odmowy wzięcia udziału w powierzonych czynnościach. Niewątpliwie projektowany art. 28a ustawy wzmocniłby prawne gwarancje prawa do sprzeciwu sumienia (i wprowadził obowiązek notyfikacyjny w przypadku odmowy wykonania zlecenia ze względu na sprzeciw sumienia $)^{40}$, niemniej trzeba pamiętać, że aktualnie również na poziomie ustawowym obowiązują przepisy formułujące dorozumianą ${ }^{41}$ klauzulę sumienia diagnosty laboratoryjnego.

\subsection{PIELĘGNIARKI I POLOŻNE}

Projekt zakłada modyfikację klauzuli sumienia zawartej w ustawie z dnia 15 lipca 2011 r. o zawodach pielęgniarki i położnej ${ }^{42}$. Przede wszystkim proponuje uchylenie przepisów nakładających na pielęgniarki i położne niekonstytucyjny obowiązek, ,wskazania realnych możliwości uzyskania tego świadczenia u innej pielęgniarki, położnej lub w podmiocie leczniczym". Ponieważ nałożony ustawowo na lekarzy obowiązek informacyjny - oznaczający współudział w realizacji czynu niegodziwego Trybunał Konstytucyjny uznał za niezgodny z art. 53 ust. 1 w zw. z art. 31 ust. 3 Konstytucji, nie ulega wątpliwości, że równie niekonstytucyjne jest zobowiązanie do tego pielęgniarek i położnych (oraz przedstawicieli innych profesji). W tym zakresie projektowana zmiana w art. 12 ust. 3 ustawy o zawodach pielęgniarki i położnej zasługuje zatem na aprobatę.

Niestety projekt pozostawia ciążący na pielęgniarce obowiązek „niezwłocznego uprzedzenia pacjenta lub jego przedstawiciela ustawowego

40 Wzmocnienie prawnych gwarancji prawa do sprzeciwu sumienia wydaje się tym bardziej zasadne, że Krajowa Rada Diagnostów Laboratoryjnych w piśmie z dnia 28 grudnia 2018 r. do Przewodniczącego Komisji Ustawodawczej Senatu RP (dostępnym na stronie: https://www.senat.gov.pl/prace/senat/proces-legislacyjny-w-senacie/inicjatywy-ustawodawcze/inicjatywa,79.html), powołując się na stanowisko V Krajowego Zjazdu Diagnostów Laboratoryjnych, skrytykowała celowość wprowadzenia klauzuli sumienia i stwierdziła, że „diagnosta laboratoryjny nie uczestniczy w zabiegach, które mogłyby być sprzeczne z jego sumieniem". To niezgodne z rzeczywistością twierdzenie wskazuje, że występująca wśród diagnostów laboratoryjnych mniejszość, dla której wykonanie konkretnych czynności diagnostyki laboratoryjnej wiąże się z dylematami etycznymi, wymaga szczególnej ochrony prawnej.

41 O różnych rodzajach klauzul sumienia w prawie polskim zob. szerzej Olszówka 2019b, 253-259.

42 Tekst jedn. Dz. U. z 2019 r., poz. 576 z późn. zm. 
bądź opiekuna faktycznego o takiej odmowie", który jest wątpliwy prakseologicznie i konstytucyjnie z racji, opisanych w pkt 3.1 niniejszej analizy. Utrzymanie tego rozwiązania jest zatem wadliwe i należy rekomendować jego uchylenie.

Projektodawca proponuje także modyfikację art. 12 ust. 2 ustawy o zawodach pielęgniarki i położnej poprzez dookreślenie, że w przypadku pielęgniarki prowadzącej indywidualną praktykę w zakładzie leczniczym na podstawie umowy z podmiotem leczniczym ma ona obowiązek poinformować ten podmiot o odmowie wykonania zlecenia lekarskiego ze względu na sprzeciw sumienia. Zmiana ta zasadniczo nie budzi wątpliwości, choć wydaje się, że dotychczasowa redakcja obejmowała i te przypadki, a przynajmniej wykładnia funkcjonalna tego przepisu pozwalała na objęcie obowiązkiem notyfikacyjnym również pielęgniarki prowadzące indywidualną praktykę ${ }^{43}$. Zauważyć trzeba, że proponowane brzmienie art. 12 ust. 2 z gramatycznego punktu widzenia jest dość skomplikowane. Nie usuwa także podstawowej wady tego przepisu, czyli takiej redakcji obowiązku notyfikacyjnego, która sugeruje, że pielęgniarka powinna informować o każdorazowym skorzystaniu ze sprzeciwu sumienia, podczas gdy wystarczająca powinna być generalna deklaracja, zasadniczo składana przez pielęgniarkę jednorazowo (z zastrzeżeniem zmiany poglądów lub zakresu świadczeń oferowanych przez podmiot leczniczy albo innych tego rodzaju sytuacji).

Znaczącą ingerencją $\mathrm{w}$ dotychczasowy kształt klauzuli sumienia pielęgniarki i położnej - wbrew deklaracjom zawartym w uzasadnieniu - jest propozycja dodania art. 12 ust. 3a, który zobowiązuje podmiot leczniczy, w którym pielęgniarka powołała się na sprzeciw sumienia, do wskazania pielęgniarki, położnej lub podmiotu wykonującego działalność leczniczą, który zapewni realną możliwość wykonania świadczenia, którego realizacji odmówiła wspomniana pielęgniarka (obowiązek informacyjny). Nie powielając w tym miejscu argumentacji zawartej w pkt 3.1 i 3.2 niniejszej analizy, należy podkreślić - za Trybunałem Konstytucyjnym - że zapewnienie realizacji takiego świadczenia, o ile mieści się $\mathrm{w}$ granicach

43 Uwagi do proponowanej redakcji art. 12 ust. 2 zgłosiła Naczelna Rada Pielęgniarek i Położnych (pismo z dnia 18 grudnia 2018 r. do Przewodniczącego Komisji Ustawodawczej Senatu RP, opublikowane na stronie: https://www.senat.gov.pl/prace/senat/proces-legislacyjny-w-senacie/inicjatywy-ustawodawcze/inicjatywa,79.html). 
prawa do ochrony zdrowia, nie powinno obarczać podmiotu leczniczego, lecz organy władzy publicznej, w szczególności NFZ, który jest instytucją najlepiej poinformowaną o zakresie udzielanych przez poszczególne podmioty lecznicze świadczeń opieki zdrowotnej finansowanych ze środków publicznych.

\section{BRAK KLAUZULI SUMIENIA FARMACEUTY}

Niestety analizowany projekt celowo pomija problem klauzuli sumienia farmaceutów. W uzasadnieniu błędnie założono, że konflikt sumienia w praktyce aptekarskiej nie występuje (,[f]armaceuta nie uczestniczy w zabiegach lub czynnościach, które mogłyby być sprzeczne z jego sumieniem"44), co jest założeniem zarówno kontrfaktycznym, jak i sprzecznym z Konstytucją. Przypomnieć należy, że prawo do sprzeciwu sumienia jest konstytucyjnym prawem człowieka, a zatem przysługuje każdemu ${ }^{45}$. W konsekwencji obowiązkiem ustawodawcy zwykłego jest uregulowanie sposobu korzystania z prawa do sprzeciwu sumienia, czyli ustanowienie tzw. klauzuli sumienia.

Warto zauważyć, że zawarte w uzasadnieniu supozycje o rzekomym braku występowania sytuacji, w których farmaceuta mógłby się powołać na sprzeciw sumienia - co należy zdecydowanie podkreślić - zostają podważone kilka zdań dalej, gdy projektodawca przyznaje jednak, że „farmaceuta nie jest pozbawiony możliwości ochrony swego sumienia, podejmując pracę w aptekach lub w miejscowościach, w których klient może

44 Druk senacki nr 1034/IX kadencja, uzasadnienie, s. 4. Równie nieprawdziwe jest stwierdzenie, że „odmowa przez farmaceutę sprzedaży wyrobu medycznego uniemożliwiałaby klientowi realizację dopuszczalnego przez prawo celu, dla którego chce z wyrobu skorzystać" (tamże), ponieważ taka odmowa nigdy nie uniemożliwia, a co najwyżej utrudnia. Na marginesie warto dodać, że z prawa do ochrony zdrowia nie wynika również, iż najbliższa apteka ma być ,nie dalej niż”. Krytyki uzasadnienia projektu w tym zakresie podjęło się Stowarzyszenie Farmaceutów Katolickich Polski w piśmie z dnia 18 grudnia 2018 r. do Przewodniczącego Komisji Ustawodawczej Senatu RP, dostępne na stronie: https://www.senat.gov.pl/ prace/senat/proces-legislacyjny-w-senacie/inicjatywy-ustawodawcze/inicjatywa,79.html.

45 Zdecydowanie podkreślają to m.in. Pawlikowski 2014, 148-149; Skwarzyński 2016, 78-80, 82-83. 
skorzystać z czynności innych farmaceutów lub aptek, nie pozbawiając w ten sposób klientów prawa dostępu do wyrobów medycznych" ${ }^{\text {"46 }}$, czym wyraźnie przeczy swej wcześniejszej tezie (pośrednio sugerując, że de lege lata farmaceuta może powołać się na sprzeciw sumienia - o czym szerzej w dalszej części).

Należy również podkreślić, iż Komisja do Spraw Petycji Sejmu RP wystosowała 25 stycznia 2018 r. do Ministra Zdrowia dezyderat ${ }^{47}$ wskazujący m.in. na konieczność przyjęcia precyzyjnych przepisów regulujących klauzulę sumienia farmaceutów. Także Biuro Analiz Sejmowych w opinii w sprawie wprowadzenia klauzuli sumienia do ustawy - Prawo farmaceutyczne zauważyło, że brak uregulowania sposobu korzystania z prawa farmaceutów do sprzeciwu sumienia stanowi lukę w obowiązującym prawie, ponieważ stawia ich w sytuacji nierównej z innymi zawodami medycznymi. Dlatego uregulowanie sposobu korzystania z prawa do sprzeciwu sumienia jest w świetle Konstytucji i prawa międzynarodowego nakaza$\mathrm{ne}^{48}$. W aktualnym stanie prawnym można wprawdzie odnaleźć dwa przepisy pozwalające wyinterpretować klauzulę sumienia dla aptekarza - są to art. 21 ustawy z dnia 19 kwietnia 1991 r. o izbach aptekarskich ${ }^{49}$ oraz art. 96 ust. 5 pkt 1 i 2 ustawy z dnia 6 września 2001 r. - Prawo farmaceutyczne $^{50}$, lecz nie jest to wyraźna klauzula sumienia, tylko odpowiednio

46 Druk senacki nr 1034/IX kadencja, uzasadnienie, s. 5.

47 Dezyderat nr 82 Komisji do Spraw Petycji z dnia 25 stycznia 2018 r. do Ministra Zdrowia w sprawie wprowadzenia klauzuli sumienia dla farmaceutów, opublikowany na stronie: http://orka.sejm.gov.pl/opinie8.nsf/nazwa/pet_d82/\$file/pet_d82.pdf [dostęp: 23.04.2019].

48 P. Bachmat, Opinia w sprawie wprowadzenia klauzuli sumienia do ustawy - Prawo farmaceutyczne, BAS-WAP-1885/17, s. 8 i 13, opublikowana na stronie: http://orka.sejm. gov.pl/petycje.nsf/nazwa/232/\$file/232.pdf [dostęp: 23.04.2019].

49 Tekst jedn. Dz. U. z 2016 r., poz. 1496 z późn. zm. Przepis ten wyraźnie nakazuje członkom samorządu aptekarskiego przestrzegać zasad etyki i deontologii zawodowej. Zgodnie zaś z art. 3 Kodeksu Etyki Aptekarza Rzeczypospolitej Polskiej (Uchwała Nr VI/25/2012 VI Krajowego Zjazdu Aptekarzy z dnia 22 stycznia 2012 r. w sprawie przyjęcia Kodeksu Etyki Aptekarza Rzeczypospolitej Polskiej, opublikowana na stronie: https://www. nia.org.pl/kodeks-etyki/) każdy farmaceuta jest zobowiązany do działania zgodnie ze swym sumieniem, co implicite potwierdza prawo do sprzeciwu sumienia.

50 Tekst jedn. Dz. U. z 2019 r., poz. 499. W świetle wykładni prokonstytucyjnej każdy z zacytowanych punktów może być intepretowany jako potwierdzający wynikające z ustawy 
dorozumiana i interpretacyjna. Ponadto zważyć należy, że nawet niektóre organy państwa kwestionują taką wykładnię, starając się pozbawić farmaceutów ich konstytucyjnego prawa do sprzeciwu sumienia, np. Rzecznik Praw Obywatelskich ${ }^{51}$.

Przepisy określające klauzulę sumienia farmaceutów nie są niczym nadzwyczajnym we współczesnych państwach demokratycznych. Takie przepisy obowiązują m.in. w wielu stanach USA (np.: Arizona, Arkansas, Południowa Dakota, Kolorado, Alabama, Teksas, Georgia, Idaho, Illinois, Missisipi, Maine) ${ }^{52}$. Ponadto Trybunał Konstytucyjny Królestwa Hiszpanii w wyroku z dnia 25 czerwca 2015 r. ${ }^{53}$ potwierdził, że farmaceuta ma konstytucyjne prawo do sprzeciwu sumienia.

Podkreślić również trzeba, iż nie jest prawdą, że osoba powołująca się na sprzeciw sumienia może jedynie odmówić wykonania (bezpośredniego

zasadniczej prawo farmaceuty do sprzeciwu sumienia w zakresie odmowy sprzedaży środków antykoncepcyjnych i postkoitalnych, ponieważ te mogą powodować zagrożenie życia lub zdrowia dziecka nienarodzonego (a także matki) - zob. szerzej Prusak 2015, 203-236.

51 Np. wystąpienie RPO z dnia 25 września 2017 r. do Ministra Zdrowia, znak VII.5002.3.2017.AMB, opublikowane na stronie: https:/www.rpo.gov.pl/sites/default/ files/Wyst $\%$ C4\%85pienie $\% 20$ do $\% 20$ Ministra $\% 20$ Zdrowia $\% 20 w \% 20$ sprawie $\% 20$ powo $\%$ C5 $\% 82$ ywania $\% 20$ si $\%$ C4\%99\%20przez $\% 20$ farmaceut $\%$ C3\%B3w\%20na $\% 20$ klauzul\%C4\%99\%20sumienia.pdf [dostęp: 23.04.2019]. Warto odnotować, że Minister Zdrowia w odpowiedzi z 5 października 2017 r., znak: PRL073.6.2017.JS.1, (opublikowanej na stronie: https://www.rpo.gov.pl/sites/default/files/Odpowied $\%$ C5\%BA\%20Ministra $\% 20$ Zdrowia $\% 20$ ws. $\% 20 \% 20$ klauzuli $\% 20$ sumienia $\% 20$ farmaceut $\%$ C3\%B3w.pdf) wskazał, że brak stosownych unormowań w ustawach ,regulujących wykonywanie zawodu farmaceuty, nie jest wystarczającą przesłanką, w świetle orzecznictwa TK, do stwierdzenia o braku możliwości powoływania się przez farmaceutów na «klauzulę sumienia»”. Podobne stanowisko Minister Zdrowia przedstawił w odpowiedzi na interpelację nr $16315 \mathrm{w}$ sprawie wolności sumienia farmaceutów (opublikowanej na stronie: http://sejm.gov.pl/Sejm8.nsf/ InterpelacjaTresc. $x$ sp?key=32C6F381\&view=5).

52 Na podstawie materiałów dostępnych na stronie: http://www.ncsl.org/research/health/pharmacist-conscience-clauses-laws-and-information.aspx (stan na wrzesień 2018 r.); por. Guttmacher Institute, Refusing to Provide Health Services, https://www.guttmacher.org/ state-policy/explore/refusing-provide-health-services.

53 Tekst wjęzykuhiszpańskim opublikowany na stronie: http://hj.tribunalconstitucional. es/en/Resolucion/Show/24527\#complete_resolucion\&votos [dostęp: 23.04.2019]. Z kolei we Włoszech Narodowy Komitet Bioetyki przyjął, że farmaceuta, powołując się na sprzeciw sumienia, może uchylić się od sprzedaży środków postkoitalnych ze względu na ich potencjalne działanie wczesnoporonne (Waszczuk-Napiórkowska 2012, 266-267). 
sprawstwa) czynu, uznanego w sumieniu za zły. W świetle orzecznictwa Trybunału Konstytucyjnego farmaceuta może powołać się na sprzeciw sumienia i odmówić wydania konkretnego produktu leczniczego (formy pośrednictwa w osiąganiu celu niegodziwego), ponieważ ,konstytucyjna gwarancja wolności sumienia chroni [...] jednostkę nie tylko przed przymusem podjęcia bezpośredniego zamachu na chronione dobro, lecz także przed takim postępowaniem niezgodnym z sumieniem jednostki, które pośrednio prowadzi do nieakceptowanego etycznie skutku, w szczególności przed przymusem współdziałania w osiąganiu celu niegodziwego" 54 . Jawnym zaprzeczeniem stanowiska TK jest pogląd - prezentowany w uzasadnieniu projektu - że farmaceuta nie może odmówić wydania środka o działaniu wczesnoporonnym czy antykoncepcyjnym, ponieważ jest tylko pośrednikiem, a odpowiedzialność za stosowanie tego preparatu ponosi wyłącznie osoba go nabywająca (i przepisujący lekarz). Człowiek, który sprzeciwia się pozbawieniu życia dziecka w początkowym okresie życia (prenatalnym) nie tylko nie może być przymuszony do bezpośredniego sprawstwa (np. wykonania aborcji), ale też udziału w takim działaniu, które może przyczynić się - choćby potencjalnie i hipotetycznie - do pozbawienia życia dziecka w okresie prenatalnym, w tym przed implantacją (np. wypisanie recepty na tabletkę ,po" czy zrealizowanie takiej recepty) ${ }^{55}$. Dostarczanie środków, które w zamierzeniu mają lub mogą uniemożliwić zagnieżdżenie dziecka w błonie śluzowej macicy (wywołują lub mogą wywołać taki skutek), przyczynia się do realizacji tego celu. Jeśli farmaceuta nie chce w takim działaniu współuczestniczyć, ma konstytucyjne prawo do odmowy wydania takiego środka i nieposiadania go we własnej aptece.

Z cytowanego wyroku Trybunału Konstytucyjnego z 2015 r. wynika również, że konstytucyjne prawo do sprzeciwu sumienia obejmuje prawo do nieudzielania informacji o osobie lub miejscu umożliwiającym dokonanie czynności, której wykonania ze względów etycznych by odmówił. W konsekwencji farmaceuta, który np. nie akceptuje swego udziału

54 Wyrok Trybunału Konstytucyjnego z 7 października 2015 r., pkt III.6.2.1 (pogr. -M.O.).

55 Szerzej na temat działania środków antykoncepcyjnych, zwłaszcza antykoncepcji hormonalnej, które mogą skutkować uniemożliwieniem zagnieżdżenia się młodego człowieka (zarodka) w ścianie macicy, co w konsekwencji równoznaczne jest z jego śmiercią na najwcześniejszym, prenatalnym etapie rozwoju zob. Prusak 2015, 203-236; Prusak 2018, 50-59. 
w sprzedaży tabletki „po”, nie może być zobowiązany do wskazania innego wykonawcy (poprzez np. odesłanie do drugiego „okienka” czy innej apteki). Czyniłoby to wolność sumienia farmaceuty (podobnie jak każdego innego przedstawiciela profesji medycznej) iluzoryczną, bo wprawdzie sam nie wydawałby „narzędzia zbrodni”, ale instruowałby, gdzie można je nabyć.

\section{POTRZEBA NOWELIZACJI (DEROGACJI) ART. 3 UST. 2 USTAWY O GWARANCJACH WOLNOŚCI SUMIENIA I WYZNANIA ORAZ ART. 135 I 138 KODEKSU WYKROCZEŃ}

Jak wynika z uzasadnienia, projektodawcy celowo rezygnują z derogacji uchwalonego przez Sejm IX kadencji PRL art. 3 ust. 2 ustawy o gwarancjach wolności sumienia i wyznania. Zasadniczo treść normatywna tej regulacji sprowadza się do ogólnego zakazu powoływania się na sprzeciw sumienia. Tym sam ustawodawca literalnie wykluczył możliwość powołania się na bezpośrednio stosowalny przepis ustawy zasadniczej poręczający wolność sumienia (art. 53 ust. 1 w zw. z art. 8 ust. 2 Konstytucji), z którego wynika, że ,[w]olność sumienia musi bowiem przejawiać się także w możliwości odmowy wykonania obowiązku nałożonego zgodnie z prawem z powołaniem się na przekonania naukowe, religijne lub moralne"56. Stan normatywny, w którym obowiązuje przepis ustawy sprzeczny z przepisem Konstytucji, trudno uznać za akceptowalny w demokratycznym państwie prawnym ${ }^{57}$. Zapewne dlatego też projektodawca zauważa, że ,[p]rawdopodobnie w nowej ustawie przepis taki nie powinien się znaleźć" 58 . Niemniej całkowicie błędnie identyfikuje skutki derogacji tego przepisu, ponieważ nie jest prawdą, iż ,jego usunięcie w obecnym kontek-

56 Wyrok Trybunału Konstytucyjnego z 7 października 2015 r., pkt III.4.4.1 (pogr. - M.O.).

57 Wprawdzie w literaturze przedmiotu przedstawiono pogląd, że zaistniałą sprzeczność można usunąć w drodze wykładni prokonstytucyjnej (Skwarzyński 2013b, 13-14), niemniej ze względu na materialną niezgodność rzeczonego przepisu ustawy z Konstytucją zachodzą poważne wątpliwości, czy w rozważanym układzie normatywnym wykładnia prokonstytucyjna jest w ogóle dopuszczalna (o granicy wykładni prokonstytucyjnej zob. np. Szczucki 2015, 294-299 i wskazana tam bibliografia).

58 Druk senacki nr 1034/IX kadencja, uzasadnienie, s. 7. 
ście normatywnym mogłoby prowadzić do wątpliwości interpretacyjnych oraz do błędnego rozpoznania skutków prawnych usunięcia tego przepisu przez adresatów niezaznajomionych z regułami systemu prawa" ${ }^{59}$. Byłoby dokładnie na odwrót. Natomiast ewentualne niepożądane skutki - które projektodawca przypisuje samej derogacji - wiążą się z niezrozumieniem, czym jest sprzeciw sumienia ${ }^{60}$.

Podobnie negatywnie należy ocenić odstąpienie od uchylenia art. 135 i 138 Kodeksu wykroczeń z powołaniem się na motywy postanowienia Sądu Najwyższego z 14 czerwca 2018 r., II KK 333/17¹. Wprawdzie Sąd Najwyższy nie zakwestionował judykatury Trybunału Konstytucyjnego eksplikującej istotę wolności sumienia, lecz nie zastosował jej w realiach rozpoznawanej sprawy, jednocześnie w sposób arbitralny odmawiając skazanemu ochrony jego konstytucyjnych wolności i praw. Przywołany w uzasadnieniu projektu werdykt Sądu Najwyższego stanowi w istocie dodatkowy argument za koniecznością uchylenia lub nowelizacji obu przepisów. Skoro judykatywa nie potrafi (lub nie chce) dokonać prokonstytucyjnej wykładni tych przepisów, wymagana jest interwencja ustawodawcy ${ }^{62}$.

59 Tamże.

${ }^{60}$ Dlatego Fundacja Instytut na rzecz kultury prawnej Ordo Iuris (podobnie jak Fundacja „Spes” - autor petycji, o której mowa w pkt 1 niniejszej analizy) zaproponowała znowelizowanie tego przepisu tak, aby wyjaśniał, na czym polega sprzeciw sumienia (projekt ustawy o zmianie ustawy o gwarancjach wolności sumienia i wyznania oraz niektórych innych ustaw w celu zapewnienia gwarancji przestrzegania prawa do sprzeciwu sumienia został opublikowany na stronie: https://ordoiuris.pl/pliki/dokumenty/Projekt_ustawy.pdf [dostęp: 23.04.2019]). Z teoretycznego punktu widzenia przepis taki oczywiście nie będzie zawierał w zasadzie żadnej nowości normatywnej, ponieważ treść prawa do sprzeciwu sumienia wynika immanentnie z art. 53 ust. 1 Konstytucji RP.

${ }_{61}$ Wyrok wraz z uzasadnieniem został opublikowany na stronie: http://www.sn.pl/sites/orzecznictwo/Orzeczenia3/II\%20KK\%20333-17.pdf [dostęp: 23.04.2019].

62 Kolejnym argumentem za potrzebą nowelizacji wymienionej ustawy jest konieczność wykonania wyroku Trybunału Konstytucyjnego z 26 czerwca 2019 r., K 16/17, stwierdzającego, że art. 138 Kodeksu wykroczeń w części zawierającej słowa ,albo umyślnie bez uzasadnionej przyczyny odmawia świadczenia, do którego jest obowiązany”, jest niezgodny z art. 2 Konstytucji. Uznanie przez Trybunał pierwszego - najszerszego - z zarzutów stawianych we wniosku Prokuratora Generalnego niejako „skonsumowało” zarzut zakresowej niezgodności zaskarżonego przepisu z art. 53 ust. 1 w zw. z art. 31 ust. 3 Konstytucji, przy czym jako niezgodny tylko $\mathrm{z}$ tym wzorcem uznał go zgłaszający zdanie odrębne sędzia TK W. Sych. Zakresowe orzeczenie sądu prawa naturalnie eliminuje - zgodnie z art. 190 Kon- 


\section{REKOMENDACJE}

Biorąc pod uwagę przedstawione powyżej argumenty, w szczególności orzecznictwo Trybunału Konstytucyjnego, należy rekomendować dokonanie w analizowanym projekcie zmian, które będą miały na celu:

I. Rezygnację z obowiązku informowania pacjenta lub jego przedstawiciela ustawowego przez powołującego się na sprzeciw sumienia lekarza i pielęgniarkę (położną) o fakcie odmowy wykonania świadczenia zdrowotnego z powodu sprzeciwu sumienia, ze względu na jego nieefektywność, konfliktogenność i niezgodność z Konstytucją.

II. Rezygnację z nałożenia na podmiot leczniczy obowiązku wskazania realnych możliwości uzyskania świadczenia, którego odmówił lekarz lub pielęgniarka, ze względu na brak instrumentarium pozwalającego na realizację tego obowiązku, a co za tym idzie nieadekwatność proponowanego mechanizmu względem celu przyświecającego projektodawcy.

III. Wykonanie wyroku Trybunału Konstytucyjnego z 7 października 2015 r., K 12/14, wskazującego na konieczność wyeliminowania mechanizmu wymuszania wykonywania przez podmiot leczniczy świadczeń „wrażliwych moralnie”, poprzez wzmocnienie ustawowych gwarancji, że podmiot leczniczy może powstrzymać się od wykonywania określonych świadczeń i usług, w szczególności aborcji.

IV. Rezygnację z nałożenia na podmiot leczniczy obowiązku wykonania zlecenia, którego odmówił diagnosta laboratoryjny, ze względu na dyskryminacyjny skutek w postaci nakazu współpracy każdego podmiotu leczniczego wykonującego czynności diagnostyki laboratoryjnej z diagnostą laboratoryjnym niezgłaszającym sprzeciwu sumienia.

V. Uregulowanie klauzuli sumienia dla farmaceutów i właścicieli aptek, którzy - podobnie jak przedstawiciele pozostałych profesji medycznych - w swej pracy zawodowej doświadczają konfliktów sumienia.

VI. Nowelizację art. 3 ust. 2 ustawy o gwarancjach wolności sumienia i wyznania poprzez zastąpienie dotychczasowej treści - pochodzącej

stytucji - z dniem ogłoszenia orzeczenia w dzienniku urzędowym, co nastąpiło 4 lipca 2019 r. (Dz. U. poz. 1238), z porządku prawnego niekonstytucyjną treść normatywną, lecz przepis ustawy jako jednostka redakcyjna tekstu aktu normatywnego pozostał w dotychczasowym brzmieniu, co rodzi konieczność nowelizacji. 
z okresu PRL - wskazaniem, że konstytutywnym elementem wolności sumienia jest prawo do sprzeciwu sumienia.

VII. Uchylenie art. 135 i 138 Kodeksu wykroczeń, uchwalonych w PRL, przynajmniej w zakresie ograniczającym wolność działalności gospodarczej (penalizacja odmowy sprzedaży towaru lub świadczenia usługi), które w praktyce sądowej bywają interpretowane w taki sposób, że naruszają konstytucyjne prawo do sprzeciwu sumienia.

\section{BIBLIOGRAFIA}

Bosek, Leszek. 2011. „Klauzula sumienia”, W: Prawo wobec medycyny i biotechnologii. Zbiór orzeczeń z komentarzami, red. Marek Safjan. Warszawa: Wolters Kluwer.

Bosek, Leszek. 2014a. „Prawo osobiste do odmowy działania sprzecznego z własnym sumieniem - na przykładzie lekarza". Forum Prawnicze 1: 14-25.

Bosek, Leszek. 2014b. „Problem zakresowej niekonstytucyjności art. 39 ustawy o zawodach lekarza i lekarza dentysty". W: Sprzeciw sumienia w praktyce medycznej - aspekty etyczne i prawne, red. Piotr Stanisz, Jakub Pawlikowski, Marta Ordon, 87-103. Lublin: Wydawnictwo KUL.

Głusiec, Waldemar, Elżbieta Puacz. 2014. „Sprzeciw sumienia w zawodzie diagnosty laboratoryjnego. W: Sprzeciw sumienia w praktyce medycznej-aspekty etyczne i prawne, red. Piotr Stanisz, Jakub Pawlikowski, Marta Ordon, 227-234. Lublin: Wydawnictwo KUL.

Johann, Wiesław, Biruta Lewaszkiewicz-Petrykowska. 1999. „Wolność sumienia i wyznania w orzecznictwie konstytucyjnym - status jednostki”. W: Wolność sumienia $i$ wyznania $w$ orzecznictwie konstytucyjnym, XI Konferencja Europejskich Sądów Konstytucyjnych, Warszawa 16-20 maja 1999. „Biuletyn Trybunału Konstytucyjnego", numer specjalny.

Kubiak, Rafał. 2014. Prawo medyczne. Warszawa: Wydawnictwo C.H. Beck.

Nawrot, Oktawian. 2014. „Prawa człowieka, sprzeciw sumienia i państwo prawa”. W: Sprzeciw sumienia w praktyce medycznej - aspekty etyczne i prawne, red. Piotr Stanisz, Jakub Pawlikowski, Marta Ordon, 105-116. Lublin: Wydawnictwo KUL.

Nawrot Oktawian. 2016. „Glosa do wyroku Trybunału Konstytucyjnego z dnia 7 października 2015 (sygn. akt K 12/14)”. Przeglad Sejmowy 4: 138-148. 
Olszówka. Marcin. 2019a. „Gwarancje i istota prawa do sprzeciwu sumienia”. W: Klauzula sumienia. Perspektywa prawnoporównawcza, red. Grzegorz Blicharz, Maciej Delijewski, 57-92. Warszawa: Instytut Wymiaru Sprawiedliwości.

Olszówka, Marcin. 2019b. „Klauzula sumienia w polskim prawie - uwagi de lege lata i de lega ferenda". W: Klauzula sumienia. Perspektywa prawnoporównawcza, red. Grzegorz Blicharz, Maciej Delijewski, 217-274. Warszawa: Instytut Wymiaru Sprawiedliwości.

Olszówka, Marcin. 2016. „Objaśnienia do art. 53 Konstytucji RP”. W: Konstytucja RP. Tom I. Komentarz do art. 1-86, red. Marek Safjan, Leszek Bosek, 649-683. Warszawa: Wydawnictwo C.H. Beck.

Orzeszyna, Krzysztof. 2017. „Klauzula sumienia jako gwarancja realizacji prawa do wolności sumienia". Medyczna Wokanda 9: 17-29.

Pawlikowski, Jakub. 2011. „Prawo do sprzeciwu sumienia w ramach legalnej opieki medycznej. Rezolucja nr 1763 Zgromadzenia Parlamentarnego Rady Europy z dnia 7 października 2010 r.". Studia z Prawa Wyznaniowego 14: 313-338. Pawlikowski Jakub. 2014. „Spór o klauzulę sumienia z perspektywy celów medycyny i etyki lekarskiej". W: Sprzeciw sumienia w praktyce medycznej-aspekty etyczne i prawne, red. Piotr Stanisz, Jakub Pawlikowski, Marta Ordon, 145-171. Lublin: Wydawnictwo KUL.

Prusak, Małgorzata. 2015. Sprzeciw sumienia farmaceutów. Aspekty etyczne, teologiczne i prawne. Kraków: Wydawnictwo św. Stanisława BM.

Prusak, Małgorzata. 2018. Bioetyka dla farmaceuty. Pelplin: Wydawnictwo Bernardinum.

Roszkiewicz, Janusz. 2018. „Spółka prawa handlowego jako podmiot wolności sumienia". W: Wolność religijna. Wybrane zagadnienia, red. Waldemar Cisło, Marcin Olszówka, Wojciech Sadłoń, 164-193. Warszawa: Pomoc Kościołowi w Potrzebie, Instytut Statystyki Kościoła Katolickiego, Instytut Ordo Iuris.

Szczucki, Krzysztof. 2009. „Klauzula sumienia - uwagi de lege lata i de lege ferenda". Studia Iuridica 50: 167-176.

Szczucki, Krzysztof. 2015. Prokonstytucyjna wyktadnia prawa karnego. Warszawa: Wydawnictwo Sejmowe.

Skwarzyński, Michał. 2013a. „Sprzeciw sumienia w adwokaturze”. W: Standardy bezstronności światopogladowej władz publicznych, red. Artur Mezglewski, Anna Tunia, 201-220. Lublin: Wydawnictwo KUL.

Skwarzyński, Michał. 2013b. „Sprzeciw sumienia w europejskim i krajowym systemie ochrony praw człowieka”. Przeglad Sejmowy 6: 9-27.

Skwarzyński, Michał. 2016. „Korzystanie ze sprzeciwu sumienia w kontekście zasady równouprawnienia i kryterium zawodu". Studia z Prawa Wyznaniowego 19: 63-88. 
Szydło Marek. 2016. „Objaśnienia do art. 31 ust. 3 Konstytucji RP”. W: Konstytucja RP. Tom I. Komentarz do art. 1-86, red. Marek Safjan, Leszek Bosek, 770-818. Warszawa: Wydawnictwo C.H. Beck.

Waszczuk-Napiórkowska, Jolanta. 2012. „Opinia prawna na temat klauzuli sumienia lekarzy, farmaceutów oraz pielęgniarek w prawie włoskim". Zeszyty Prawnicze Biura Analiz Sejmowych 3: 257-268.

Zoll, Andrzej. 2014a. „Charakter prawny klauzuli sumienia”. Medycyna Praktyczna 1: 99-103, 116.

Zoll, Andrzej. 2014b. „Klauzula sumienia”. W: Sprzeciw sumienia w praktyce medycznej - aspekty etyczne i prawne, red. Piotr Stanisz, Jakub Pawlikowski, Marta Ordon, 77-85. Lublin: Wydawnictwo KUL.

\author{
ANALYSIS OF THE DRAFT LAW AMENDING THE ACT \\ ON THE PROFESSIONS OF PHYSICIAN AND DENTIST, \\ THE ACT ON LABORATORY DIAGNOSTICS AND THE ACT \\ ON THE PROFESSIONS OF NURSE AND MIDWIFE, \\ CONTAINED IN THE SENATE PAPER NO. 1034/IX TERM OF OFFICE \\ (CONSCIENTIOUS OBJECTION) ${ }^{63}$
}

\title{
Summary
}

Conscientious objection is a refusal to fulfil the obligation that arises from the law due to one's reasonably justified moral judgment that qualifies fulfilling this obligation as ethically wrong (objective evil). The right to conscientious objection, which is an integral element of freedom of conscience, is a constitutional right of every human being. As emphasised by the Constitutional Tribunal of the Republic of Poland in the judgment of 7 October 2015 (K 12/14): "the right to invoke the conscience clause and, as a result, the right to refuse to perform an act contrary to one's conscience is the guarantee of freedom of conscience". Regulating the use of the right to conscientious objection, that is, establishing the so-called conscience clause, is the responsibility of the ordinary legislator.

The draft legislation amending the Act on the professions of physician and dentist, the Act on laboratory diagnostics and the Act on the professions of nurse and midwife, adopted by the Human Rights, the Rule of Law and Petitions Com-

63 The present paper is an updated and slightly extended version of the analysis published on the website of Ordo Iuris on 29 January 2019: https:/ordoiuris.pl/wolnosc-sumienia/ analiza-projektu-ustawy-o-zmianie-ustawy-o-zawodach-lekarza-i-lekarza-dentysty. 
mittee of the Senate of the Republic of Poland, was supposed to regulate the conscience clause in medical professions, realise the petition to revoke art. 3 para. 2 of the Act of 17 May 1989 on guarantees of freedom of conscience and religion, which generally prohibits the invocation of conscientious objection, and implement the above-cited judgment of the Tribunal in a comprehensive way.

Although this initiative deserves approval, the current text of the draft law proves that the judgment of the Tribunal will be implemented only to a limited extent. It ignores the request made in the petition and lowers the statutory standard of protection of the right to conscientious objection.

First of all, it is questionable that healthcare entities (e.g., manager of hospitals) would be obliged to indicate real possibilities of obtaining a service refused by a physician or nurse (midwife), and, in the case of a laboratory diagnostician, to perform a service. This is contrary to freedom of conscience, which means, as noted by the Constitutional Tribunal, protection from conduct "which indirectly leads to an unacceptable ethical effect, [and] in particular [protection] from coercion to cooperate in achieving an immoral goal" (e.g., from the obligation to inform a patient who can perform an abortion and where it can be performed). At the same time, the draft law questions the so-called institutional conscience clause, which the Parliamentary Assembly of the Council of Europe requested to respect in Resolution no. 1763 of 7 October 2010.

Key words: conscientious objection; conscience clause; freedom of conscience; medical professions; supremacy of the constitution 